\title{
SYMBOLIC AND PROPHETIC SYNTAGMAS IN CHINUA ACHEBE'S ANTHILLS OF THE SAVANNAH
}

\author{
Omowumi Bode Steve Ekundayo \\ Department of English and Literature, University of Benin, Benin City, Nigeria \\ Email: ekuns20@yahoo.com \\ Abiola Olubunmi Akinbobola \\ Department of English, University of Lagos, Nigeria \\ Email: abiola.akinbobola36@gmail.com
}

APA Citation: Ekundayo, O. B. S., \& Akinbobola, A. O. (2016). Symbolic and prophetic syntagmas in Chinua Achebe's Anthills of the Savannah. English Review, $4(2), 181-194$

\begin{abstract}
This essay discusses Achebe's delineation of characters, events and use of language in Anthills of the Savannah (AS) as symbolic and prophetic syntagmas which later manifested in some real life personalities and socio-political phenomena in Africa and Nigeria, the setting of the novel. The primary source of data is Anthills of the Savannah. Secondary source and the internet were also consulted for the theoretical background and literature review. Grammatical structures and literary features were extracted and analyzed to show their associative and symbolic links with real life events which occurred after 1987, the year $A S$ was published. The symbolic and prophetic syntagmas identified and their manifestations are presented with annotations in tables. The essay established that Achebe uses syntagmas of utterances, events, settings and characters to symbolize and foreshadow imminent events in the novel and socio-political occurrences in Nigeria and Africa, a feat which stands him out as a novelist with great prophetic insight and clairvoyance.
\end{abstract}

Keywords: Achebe, AS, syntagma, prophetic, symbolic. Character

\section{INTRODUCTION}

Albert Chinua Achebe, who died on the 21st of March, 2013, is Africa's most celebrated novelist till date. AS is Achebe's fifth novel. It is set in Kangan, an imaginary West African country, where Sam, "His Excellency," a Sandhurst-trained military officer, has ceased power in a military coup. Achebe portrays the political anomy through the ordeals of three friends: Chris Oriko, the Commissioner for Information, Beatrice Okoh, Chris' girlfriend who is also an official in the Ministry of Finance, and Ikem Osodi, a newspaper editor, critic and activist. Other characters include Elewa, Ikem's girlfriend, and Major
"Samsonite" Ossai, a military officer who is notorious for stapling his victims' hands with a Samsonite stapler. Tension and conflicts culminate in the assassination of Ikem, toppling of the military junta, death of Sam and finally the sudden and unnecessary murder of Chris in a police check-point. The novel ends in the creative naming ceremony of Elewa and Ikem's one-month-old daughter organized by Beatrice. The girl is named 'Amaechina,' a male name imposed on a female child, meaning 'may the path never close.'

The essay sets out to answer the following questions: 
(i) Are there utterances in AS that symbolize and forebode futurity and preempt future events?

(ii) Are there characters in AS whose facsimiles later emerged in real Nigerian and African life after the publication of $A S$ ?

(iii) Are there events and scenes in $A S$ which later manifest in real Nigerian and African life after the publication of the novel?

(iv) What are the implications of the symbolic and prophetic syntagmas for creative writing in general and Achebe in particular?

The essay is based on Ferdinard de Saussure's concept of syntagma and the literary concept of symbolism. Saussure (1966, p. 123) asserts that "in discourse,... words acquire relations based on the linear nature of language because they are chained together... and that "combinations supported by linearity are syntagm(a)s." Saussure further says that "the syntagmatic relation is... based on two or more items that occur in an effective series"(p. 123). Saussure says that "the notion of syntagm(a)s applies not only to words, but to group of words, complex units of all kinds, lengths and types (compounds, derivatives, phrases, whole sentences)" (p. 124). Even though some terms in the definitions above are similar to syntax; for example, "combination of words" and "linear," syntagma is not the same as syntax. Saussure says that "not every syntagmatic fact belongs to the syntactic class" (p.137) because syntax deals with how units combine in linearity.

Syntagm(a)s do the same but they can be extended, as in the following extract:

When you hear Ikem Osodi! Ikem Osodi! Everywhere, you think his head will be touching the ceiling. But look at him, how simple he is... (AS, p. 121)... 'I never meet you before in person sir' said the superintendent springing out from behind his massive wooden desk. 'Very pleased to meet you sir. I was expecting a huge fellow like this' and he made a sign sideways and upward.

'No, I am quite small. Anyone who feels like it can actually beat me up quite easily.' (AS, pp. 130-131)

It is impossible to analyze this text as a whole syntactically except we fragment it into individual sentences and then analyze them one after another; for instance:

S $\quad \mathrm{V} \quad \mathrm{C}$

$S$

$\mathrm{V} \quad \mathrm{O}$

I / am / quite small..., / Anyone who feels like it/can beat/me...'/, etc.

However, in syntagmatic analysis, the whole structure can be analyzed as a syntagma, such that all the sentences in the text merge to form one unit, which delineates Ikem, as in the schema below: 
Figure 1.A Schema of the Analysis of a Character Syntagma

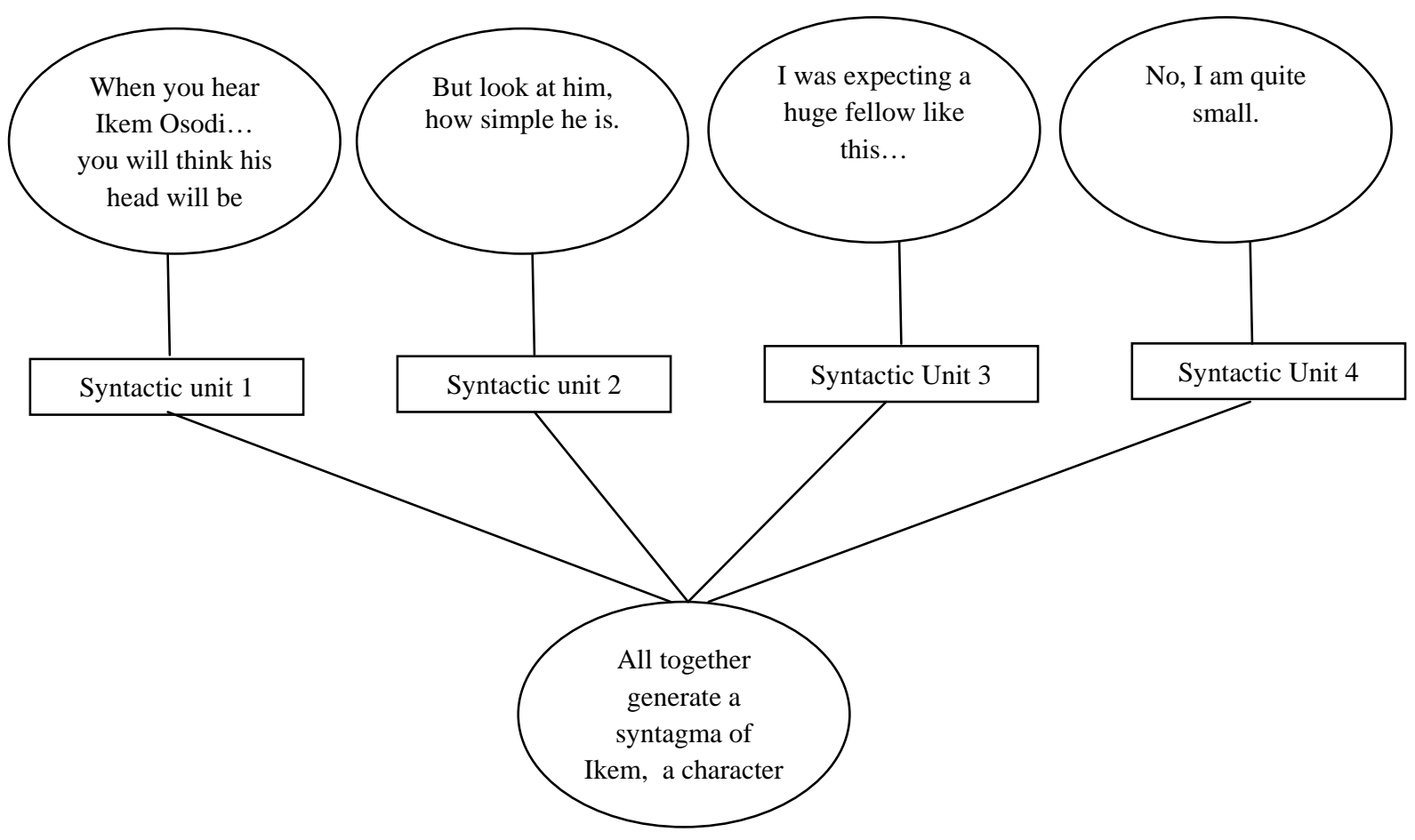

Because many linguistic units which are normally the limits of syntactic analysis can be found in one syntagma, Saussure states that syntactic facts fall under syntagmatic classifications. There is another part of syntagma which relates with meanings that derived from the structures or combinations of linguistic elements. Saussure calls them 'associative relations' (p.123). Richards, Platt and Platt (1992, p. 369) defines syntagma as "a structurally significant combination of two or more units in a language."

Crystal (2009) says that "in PSYCHOLINGUISTICS the term is sometimes used to refer to a set of associative response which people make when hearing a stimulus word...a syntagmatic associative response would be... car, ... sheep following black" (pp. 470-471), as in 'a black sheep,' 'a black car,' 'a black man,' etc. because the structure '---sheep,' '---man' can be collocatively or associatively completed with the words 'black' or 'white' respectively. Saussure and Crystal make it clear that a syntagma can stand as a symbol which calls to mind other meanings or associations. Here, the syntagmas have been given symbolic associations with historical events in real life, as shown in figure 2 below: 
Figure 2. A Schema of Associative Relations of Syntagmas

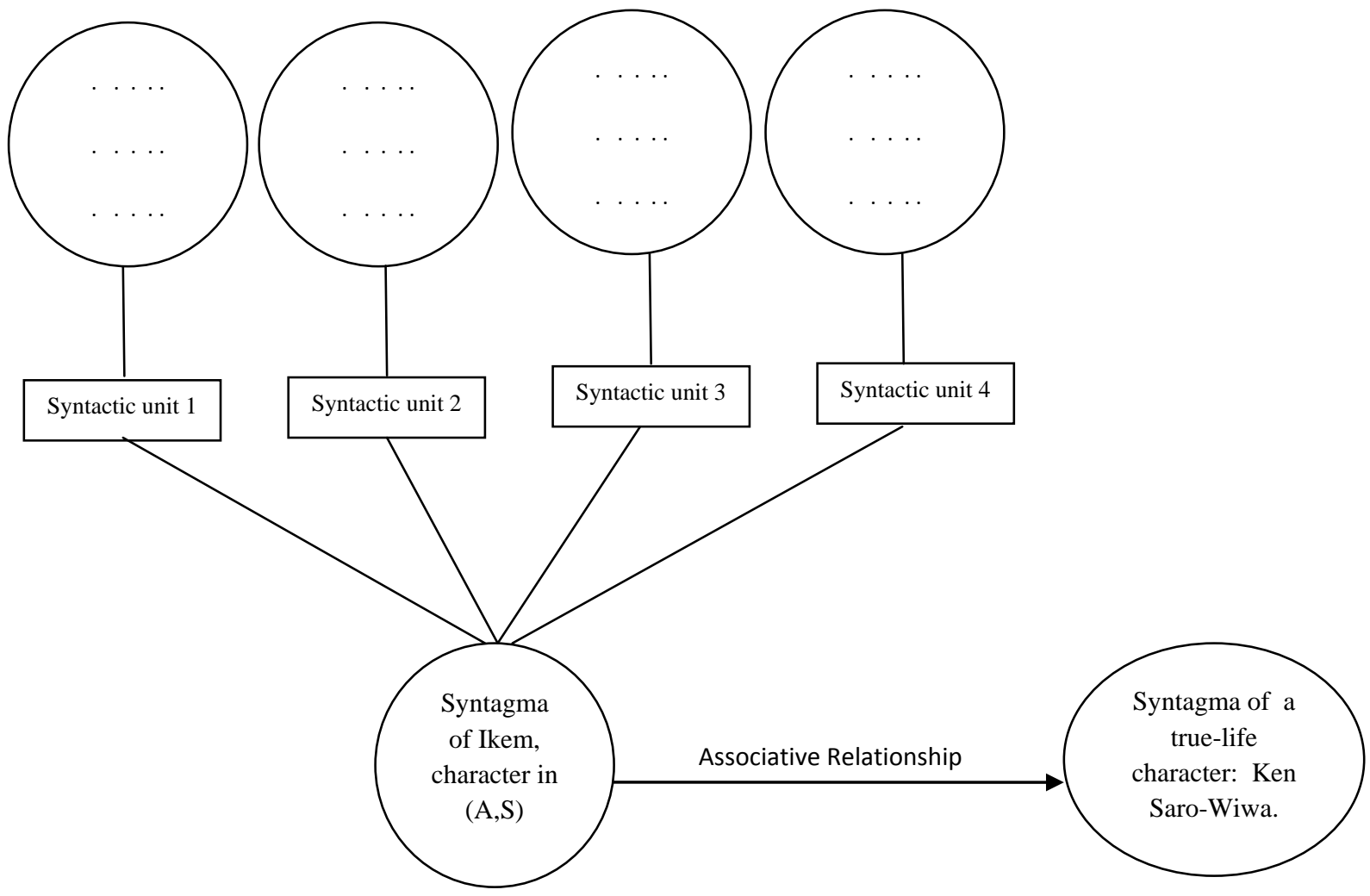

Prophetic syntagmas in the sense of this essay are combinations of linguistic units and literary features in AS that correspond with events that occurred after $A S$ was published. Sometimes, the meaning of syntagmas can be derived by reinterpretation, juxtaposition and association with something else. For example, in this essay, some symbolic syntagmas are identified based on a consideration of history, so that they are analyzed as prophetic syntagmas not necessarily because the structures on the surface depict them as such, but because they happened many years after they had been written in $A S$.

There is a sense in which linguistic syntagma dovetails with symbolism. As a syntagma denotes or connotes something, a meaning, so does symbolism or symbol stand for something else. An on-line source (http://literarydevices.net/symbolism/) defines symbolism as follows:

Symbolism is the use of symbols to signify ideas and qualities by giving them symbolic meanings that are different from their literal sense. Symbolism can take different forms. Generally, it is an object representing another to give it an entirely different meaning that is much deeper and more significant. Sometimes, however, an action, an event or a word spoken by someone may have a symbolic value. For instance, "smile" is a symbol of friendship. Similarly, the action of someone smiling at you may stand as a symbol of the feeling of affection which that person has for you.

Symbols do shift their meanings depending on the context they are 
used in. "A chain", for example, may stand for "union" as well as "imprisonment." Thus, symbolic meaning of an object or an action is understood by when, where and how it is used. It also depends on who reads them.

This definition agrees with Abrams and Harpham's (2009) definition of symbol as 'a word or phrase that signifies an object or event which in its turn signifies something, or suggests a range of reference, beyond itself... Often, they do so by exploiting widely shared associations between an object or event or action and a particular concept...' Accordingly, in this paper certain linguistic structures: words, phrases and sentences, and some literary features: characters, events and settings are identified and analyzed as symbolic of a number of post- $A S$ socio-political events and personalities in Nigeria and Africa.

Now, we review some views related to the discussion of syntagmatic relation in language and art works, critical comments on $A S$ and the deployment of language in $A S$. In a work on the syntagmas of cinema, Adrian Miles (2000, p. 1) quotes Christian Metz, who is a pioneer in the use of this method, as follows:

Christian Metz argued that the major mode of analysis for cinema (and by implication, hypertext) was based on syntagmatic relations, that is, meaning is principally developed and articulated through the expression of a partially autonomous temporary chain.

'Autonomous temporal chain' here reminds us of the coming together of individual linguistic units in syntagmas; "for the significant narrative unit identified by Metz is not the shot (the hypertext node) or the relation of one shot to another (the edit), but is in fact the larger sequential units produced by the combinations of shots" (1). Miles underscores the aspect of associative relations which relates to meanings. According to him, "Metz's work demonstrates the strongly contextual nature of these syntagmatic series... the success of Metz's categories for hypertext lies not so much in their direct applicability but in allowing us to cast light on the role of syntagmatic segments in the production of meaning in hypertext" (1). Miles' essay establishes that syntagmas have a context of usage; that is, their environment or situation. Syntagmatic segments have a role in the production of meanings. Metz and Miles'views of syntagmas correspond with our analysis in this essay, which shows that syntagmas are combinations of linguistic units and meaninggenerating segments.

Anita Silvers (1991) applies

"Revisionism" to analyze AS."

Revisionism "is the view that in valuing art, it is essential to understand (some) historical events which occur after a work was made..." (211). Silvers establishes that the knowledge of historical events could reveal that language has been used by a writer to discuss some events that will happen later. Accordingly, this essay shows how Achebe has used language and literary features to present some events that happened later. Achebe's literary prowess in this regard became established with his A Man of the People (1996). The novel chronicles series of socio-political anomies that culminate in a military coup. Indeed, shortly after its publication, the first military coup was executed in Nigeria. Umukoro (2009, pp.16, 22, 24) likens the incidents in $A$ Man of the People to some real political events in Nigeria. Ekundayo and Iyayi 
(2012, p. 90) discuss the prophetic nature of Achebe's AS:

In Anthills of the Savannah, for example, Achebe presents the shape of things to come... the killing of Ikem, the hero, forecasts the hanging of Ken Saro-Wiwa ten years later...the birth of Amaechina, which in Ibo means 'may-the-path-never-close', foreshadows and symbolizes the rise of women to the foreground of politics and leadership in Africa and Nigeria. This literary forecast is being fulfilled in real African politics in the emergence of Johnson Sirleaf as the first female African President of Liberia (p. 90).

It is noteworthy that their essay briefly presents the fulfilment of Achebe's prophetic syntagmas. Little did Festus Iyayi, a fellow writer, activist, intellectual and Ken Saro Wiwa's friend, know that he himself was going to be killed a year after his paper quoted above in about the same way in which Chris, a major Character in $A S$, was killed. Ekundayo and Iyayi's essay only makes passing comments on the prophetic nature of $A S$ using examples of two characters, Ikem and Amaechina while this study exemplifies ten characters and carries out an in-depth analyses of all of them in addition to those of settings, events and utterances.

In a newspaper review, a critic says that Anthills of the Savannah is "a vision of social change that strikes us with the force of prophecy..." (USA Today). Here, there are clear references to the prophetic deployment of language by Achebe in AS. However, the article did not go further to identify and analyze the specific prophetic structures in the novel and how they have come to pass, as has been done in here. Ogiovoh (2005, p. 41) establishes that Achebe delineates Beatrice to give readers "prophetic insight into future events and issues", but no mention of the events are made, as in this paper. This paper analyzes the syntagmas of utterances, events, settings and characters for their prophetic relevance, paying attention to how these syntagmas have come to pass in the novel and in the larger society. In $A S$, Achebe's deployment of utterances, events, settings and characters later correspond with the emergence of distant socio-political occurrences and personalities in Nigeria and Africa, a feat that marks Achebe out as a novelist with great prophetic insight and clairvoyance.

\section{METHOD}

The paper is basically qualitative. The primary source of data is AS from which language and literary features were extracted, analysed and juxtaposed with post- $A S$ events and people in Nigeria and Africa in order to underscore their uncanny resemblance to each other. Secondary sources and the Internet were also consulted for literature review and comments on Achebe's works. The method of analysis is descriptive and explanatory. Some of the syntagmas identified are presented in tables, matched with events and personalities that emerged on the Nigerian and African socio-political scene after the publication of the novel.

\section{RESULTS AND DISCUSSION}

The prophetic and symbolic utterances are identified and analyzed from morphological and collocational or syntactic perspectives. The morphological angle looks at individual lexical items and utterances that are prophetic while the collocational or syntactic deals with phrases, clauses and sentences, in addition to a discussion of events and characters as symbolic syntagmas. 


\section{Name and Lexical Items as Prophetic Syntagmas}

Some names in AS possess prophetic qualities and undertones. Many of these names are in the Igbo language, a major Nigerian language. They are presented in the table below.

Table 1:

A Table of Names as Prophetic and Symbolic Syntagmas

\begin{tabular}{|c|c|c|c|c|c|}
\hline $\mathrm{S} / \mathrm{N}$ & Name & Page & Meaning & Context & Prophetic Relevance \\
\hline 1 & Nwayibuife & 87 & $\begin{array}{l}\text { 'A female is also } \\
\text { something.' }\end{array}$ & $\begin{array}{l}\text { Beatrice's name at a time } \\
\text { when her parents desired } \\
\text { a male child. }\end{array}$ & $\begin{array}{l}\text { It underscores the } \\
\text { importance of females who } \\
\text { also possess the ability to } \\
\text { rise up in the future. }\end{array}$ \\
\hline 2 & Nkolika & 124 & $\begin{array}{l}\text { Recalling } \\
\text { greatest. }\end{array}$ & $\begin{array}{l}\text { Ikem says that the name } \\
\text { is sometimes given to } \\
\text { daughters for the } \\
\text { importance of the } \\
\text { symbolic "story': } \\
\text { "because it is only the } \\
\text { story that can continue } \\
\text { beyond the war and } \\
\text { warrior." }\end{array}$ & $\begin{array}{l}\text { It is a call on a people to } \\
\text { retrace their steps, look back } \\
\text { and re-chart the course for } \\
\text { progress. "For the story of a } \\
\text { people outlives the people } \\
\text { and will have to be told at } \\
\text { any rate." }\end{array}$ \\
\hline 3 & Shearjashub & 222 & $\begin{array}{l}\text { The-remnant- } \\
\text { shall-return }\end{array}$ & $\begin{array}{l}\text { This is a biblical allusion } \\
\text { to the book of Isaiah } 7: 3 \text {. }\end{array}$ & $\begin{array}{l}\text { The statement is a futuristic } \\
\text { one depicting hope for Israel } \\
\text { captives and now an } \\
\text { indictment of Nigeria. }\end{array}$ \\
\hline 4 & Amaechina & 22 & $\begin{array}{l}\text { May-the-part- } \\
\text { never-close } \\
\text { (structurally, it } \\
\text { is a future wish } \\
\text { presented in the } \\
\text { subjunctive } \\
\text { present). }\end{array}$ & $\begin{array}{l}\text { Amaechina is the male } \\
\text { name of Elewa and } \\
\text { Ikem'sdaughter. }\end{array}$ & $\begin{array}{l}\text { Ikem stands for the struggle, } \\
\text { truth and equality. The } \\
\text { name forecasts the rise of } \\
\text { women in politics: the path } \\
\text { Ikem trod will not close. }\end{array}$ \\
\hline 5 & Agbata & 208 & $\begin{array}{l}\text { This is the land } \\
\text { where Chris } \\
\text { was killed. }\end{array}$ & $\begin{array}{l}\text { "...the land of } \\
\text { droughts...the famous } \\
\text { dusty and bustling } \\
\text { market town of Agbata." }\end{array}$ & $\begin{array}{l}\text { It foreshadows drought, } \\
\text { lawlessness, anomy and } \\
\text { political disorder as seen to } \\
\text { exist in Nigeria in the past, } \\
\text { present and in the future. }\end{array}$ \\
\hline
\end{tabular}

\section{Collocational/Syntactic Prophetic Syntagmas}

Table 2.A Table of Utterances as Prophetic Syntagmas

\begin{tabular}{|c|c|c|c|c|}
\hline $\mathrm{S} / \mathrm{N}$ & Example & Page & Structural Pattern & Symbolic Relevance \\
\hline 1 & $\begin{array}{l}\text { "We shall never be favoured } \\
\text { with such an undeserving } \\
\text { blessing as a ruthless } \\
\text { dictator." }\end{array}$ & 3 & $\begin{array}{l}\text { There is the use of } \\
\text { 'shall' in the first person } \\
\text { to depict futurity. The } \\
\text { verb phrase 'shall never } \\
\text { be favoured' is the focal } \\
\text { point of futurity. }\end{array}$ & $\begin{array}{l}\text { The statement is an irony. It is a } \\
\text { prayer that underscores the } \\
\text { possibility of the emergence of } \\
\text { dictators in future, which the } \\
\text { prayer forbids. }\end{array}$ \\
\hline
\end{tabular}




\begin{tabular}{|c|c|c|c|c|}
\hline \multirow[t]{2}{*}{2} & "The future she saw & 170 & The verb phrase 'would & \multirow{2}{*}{$\begin{array}{l}\text { This anticipates the future active } \\
\text { and courageous involvement of } \\
\text { women in politics and the } \\
\text { struggle for social change. }\end{array}$} \\
\hline & $\begin{array}{l}\text { unfolding so relentlessly } \\
\text { before them would demand } \\
\text { brutal courage not } \\
\text { squeamishness, from the } \\
\text { likes of Elewa and herself } \\
\text { from now on." }\end{array}$ & & $\begin{array}{l}\text { demand' denotes strong } \\
\text { possibility } \\
\text { necessity. 'From now } \\
\text { on' is a cataphoric } \\
\text { reference to the } \\
\text { continuum of the } \\
\text { present and future. }\end{array}$ & \\
\hline 3 & $\begin{array}{l}\text { "Don't give up, whatever is } \\
\text { hot will become cold." }\end{array}$ & 199 & $\begin{array}{l}\text { It is presented in } \\
\text { analytic truth, which is } \\
\text { truth according to } \\
\text { nature. Modal auxiliary } \\
\text { (will) + lexical } \\
\text { (become). }\end{array}$ & $\begin{array}{l}\text { The 'mother bed-bug' tells her } \\
\text { children this when hot water } \\
\text { was poured on them and they } \\
\text { were about to give up. It } \\
\text { symbolically or proverbially } \\
\text { announces hope and imminent } \\
\text { change from chaos to peace, } \\
\text { from discomfort to comfort. }\end{array}$ \\
\hline 4 & $\begin{array}{l}\text { "After the anthem shall } \\
\text { have been played } \\
\text { backwards." }\end{array}$ & & $\begin{array}{l}\text { It is rendered in the } \\
\text { future perfect to denote } \\
\text { possibility. }\end{array}$ & $\begin{array}{l}\text { It forebodes a disruption or } \\
\text { reversal of social and national } \\
\text { order. }\end{array}$ \\
\hline 5 & $\begin{array}{l}\text { "You young people, what } \\
\text { you will bring this world to } \\
\text { is pregnant and nursing a } \\
\text { baby at the same time." }\end{array}$ & 227 & $\begin{array}{l}\text { The above extract uses } \\
\text { 'will' to predict the } \\
\text { future. }\end{array}$ & $\begin{array}{l}\text { It is a symbolic charge to the } \\
\text { people not to underrate the } \\
\text { young generation, a paradoxical } \\
\text { utterance showing the } \\
\text { unpredictable nature of the } \\
\text { youths. }\end{array}$ \\
\hline 6 & $\begin{array}{l}\text { "I want to remind you of } \\
\text { that little discussion we all } \\
\text { had after the Entebbe raid. } \\
\text { You remember? You all said } \\
\text { then, what a disgrace to } \\
\text { Africa....remember...I said } \\
\text { it could happen here. Right } \\
\text { here." }\end{array}$ & 15 & $\begin{array}{l}\text { It is presented in a } \\
\text { conversational } \\
\text { structure. The use of } \\
\text { 'could' depicts futurity } \\
\text { and possibility. }\end{array}$ & $\begin{array}{l}\text { Here, Achebe's character } \\
\text { remembers a past event and says } \\
\text { that it can happen again and it } \\
\text { did happen, for history often } \\
\text { repeats itself. }\end{array}$ \\
\hline
\end{tabular}

Syntagmas 4, 5 and 6 are noteworthy here. The world that was ruled and controlled by a body of elders before has now come to be controlled by the youths who have become so innovative and trendy that they have succeeded in phasing out many stringent traditions. On the negative side, the youths have become restless, restive, violent, inordinate and unpredictable these days. Hence they are likened to a woman breastfeeding and yet pregnant at the same time. The National Anthem of Nigeria seems as though it is being played backwards. The next section examines symbolic and prophetic events and settings.

\section{Events and Settings as Symbolic Syntagmas}

Syntagmas of events, settings and characters are interwoven because events take place in a particular place and at a particular time, which is known as setting or locale. Characters instigate or initiate events which they complete or abandon in a literary work. However, character syntagmas are examined in sub-section (3.5). 
Table 3.A Table of Events and Settings as Prophetic Syntagmas

\begin{tabular}{|c|c|c|c|c|}
\hline $\mathrm{S} / \mathrm{N}$ & Events & Page & Setting & Symbolic/Prophetic implications \\
\hline 1 & $\begin{array}{l}\text { A rich lady vomits on } \\
\text { the back of a man and } \\
\text { cleans it up with her } \\
\text { expensive damask head } \\
\text { tie. }\end{array}$ & 41 & $\begin{array}{l}\text { The beach where } \\
\text { criminals are being } \\
\text { executed before an } \\
\text { excited crowd. }\end{array}$ & $\begin{array}{l}\text { It is symbolic and prophetic of the rich } \\
\text { and wealthy people who have come to } \\
\text { watch the downfall of the lowly ones } \\
\text { being executed. The rich will also clean } \\
\text { their mess at the expense of their wealth in } \\
\text { public. }\end{array}$ \\
\hline 2 & $\begin{array}{l}\text { The birth and naming } \\
\text { ceremony of } \\
\text { Amaechina. }\end{array}$ & 222 & $\begin{array}{l}\text { Beatrice Okoh's } \\
\text { house before his } \\
\text { friends. }\end{array}$ & $\begin{array}{l}\text { It symbolizes/foreshadows the rise of } \\
\text { women in politics and activism, as it is } \\
\text { happening now all over Africa. }\end{array}$ \\
\hline 3 & $\begin{array}{l}\text { Aina, Buraimoh's wife, } \\
\text { a Moslem, dances to } \\
\text { Agatha's Christian } \\
\text { song, saying “dem talk } \\
\text { sey make Moslem no } \\
\text { dance when Christian } \\
\text { de sing? }\end{array}$ & 224 & $\begin{array}{l}\text { Beatrice's house, } \\
\text { around the time } \\
\text { Amaechina is born. }\end{array}$ & $\begin{array}{l}\text { This foreshadows the unity of Muslims } \\
\text { and Christians. It is a rhetorical question } \\
\text { that has future significance. It may come } \\
\text { to pass one day. }\end{array}$ \\
\hline 4 & The coups in the novel. & 222 & $\begin{array}{l}\text { Contexts of socio- } \\
\text { political power and } \\
\text { national leadership. }\end{array}$ & $\begin{array}{l}\text { The coups foretells coup in Africa. After } \\
\text { 1987, the year AS was published, many } \\
\text { coups took place and are still taking place } \\
\text { in Nigeria and some other African } \\
\text { countries. }\end{array}$ \\
\hline
\end{tabular}

\section{Characters as Prophetic/Symbolic Syntagmas}

Achebe in $A S$ delineates characters whose facsimiles emerged later in contemporary events in Nigeria and Africa. First, we look at the major characters.

\section{Major Characters as Symbolic Syntagmas}

In this sub-section, major characters in the novel are analyzed for evidence of associative relationships with other personalities that have played up in real life after the publication of $A S$.

Table 4.

A Table of Major Characters as Prophetic Syntagmas

\begin{tabular}{|c|c|c|c|c|}
\hline $\mathrm{S} / \mathrm{N}$ & Character & page & Setting/context & Prophetic Relevance \\
\hline 1 & Sam & $\begin{array}{l}\text { Many } \\
\text { pages. }\end{array}$ & $\begin{array}{l}\text { In many scenes and } \\
\text { events. }\end{array}$ & $\begin{array}{l}\text { Sam is a prophetic archetype of tyranny, visionless } \\
\text { leadership and corruption for which African } \\
\text { military and political leaders are notorious. }\end{array}$ \\
\hline 2 & Ikem & $\begin{array}{l}\text { Many } \\
\text { pages. }\end{array}$ & $\begin{array}{l}\text { Many scenes and } \\
\text { events. }\end{array}$ & $\begin{array}{l}\text { He is a symbol of truth, boldness, selflessness, } \\
\text { martyrdom, etc. He has associative relations with } \\
\text { the late Ken Saro-Wiwa. (See comments below). }\end{array}$ \\
\hline 3 & Beatrice & $\begin{array}{l}\text { Many } \\
\text { pages. }\end{array}$ & $\begin{array}{l}\text { Many events and } \\
\text { scenes. }\end{array}$ & $\begin{array}{l}\text { She symbolizes the rise of women. She has } \\
\text { associative relations with Ellen Johnson Sirleaf, } \\
\text { first female president in Africa, and many other } \\
\text { great women emerging in Africa. }\end{array}$ \\
\hline 4 & Chris & $\begin{array}{l}\text { Many } \\
\text { pages. }\end{array}$ & $\begin{array}{l}\text { Many events and } \\
\text { scenes. }\end{array}$ & $\begin{array}{l}\text { Chris is a symbol of courage and martyrdom. He } \\
\text { has associative relations, for instance, with the } \\
\text { dastardly manner in which Professor Festus Iyayi } \\
\text { was shot dead in a so-called road accident. }\end{array}$ \\
\hline 5 & Amaechina & 222 & $\begin{array}{l}\text { She was born after } \\
\text { the death of her } \\
\text { father, }\end{array}$ & $\begin{array}{l}\text { Amaechina foretells the rise of women. The name } \\
\text { has associative relations with great African female } \\
\text { leaders like Dora Akunyuli, Johnson Sirleaf and }\end{array}$ \\
\hline
\end{tabular}


protagonist of the novel, at a time Kangan is in anarchy. many women who are now playing active roles in

African politics and leadership.

Ikem in the text has an uncanny resemblance to Ken Saro Wiwa physically and ideologically. As at 1987, Achebe creates a character that foreshadows the emergence of another personality in Nigerian history in 1995. In Ikem, Achebe prophetically delineates Ken Saro Wiwa. Both Ikem and Ken Saro Wiwa share some physical features and professional attributes. For example, Saro-Wiwa is as short as Ikem. Ikem is a blunt and bold writer and a journalist who is on the side of the masses. Similarly, Ken Saro-Wiwa is a creative writer, television producer and activist who was bold and fearless in his attack on political anomalies. Achebe's Ikem bears uncanny resemblance to Ken, a man who is selfless, embodying the Marxian direction of social change. He "satisfies the Marxist demand that intellectuals should follow their example and lose themselves amidst the masses... He champions the common cause in his editorials, keeps an affair with an illiterate woman and rides a decrepit car" (Owomoyela, 2002, p. 2) to associate with the masses. "It is through Ikem Osodi that Achebe explores the true role of the artist in the contemporary African society" who should have vision and "direct their society in the path that it should be heading" (Ojinmah, 1991, p. 99).

Again, the way Ikem was eliminated in AS in 1987 forebodes and pre-describes Ken Saro-Wiwa's death in Nigeria. For example, Ikem is first arrested and taken away: "In the early hours of this morning, a team of security officers effected the arrest of Mr. Osodi in his official flat... and were taking him in a military vehicle for questioning at 
ENGLISH REVIEW: Journal of English Education Vol. 4, Issue 2, June 2016
ISSN 2301-7554

https://journal.uniku.ac.id/index.php/ERJEE the SRC headquarters...."(AS, p. 169). Similarly, "Saro-Wiwa was arrested, hastily tried by a special military tribunal"

(Wikipediaonlinekensarowiwa).Subsequ ently, Ikem is killed unjustly in baffling and inscrutable circumstances:" Ikem was not just wounded but dead. He was convinced that the drafters of the government statement had deliberately chosen a phrase which was popularly misunderstood" (AS,p. 170). Ken SaroWiwa, like Ikem, was also hanged precipitously on $10^{\text {th }}$ November 1995. "Mr. Saro-Wiwa's body was burned with acid and thrown in an unmarked grave" (Reuters, 2013) in the same way Ikem's body is not found to be given a befitting burial.

Both the extermination of Ikem in $A S$ and Saro-Wiwa in Nigeria generated internal and external ferment and disaffection. For Ikem, Achebe writes that "before evening both systems, foreign and local, seemed set to start buzzing in the interest of the abducted man" (AS, p. 168). Also, for Saro-Wiwa, it is said that his "execution provoked international outrage and resulted in Nigeria's suspension from the Commonwealth of Nations for over three years" (Wikipediaonline).In the light of this, Ikem is a prophetic and symbolic syntagma who showed up seven years later in Ken Saro Wiwa.

Beatrice at different instances takes up male roles and succeeds in them: "She is possessed by a need to deliver her people... and in part to fulfill her own destiny within the new dispensation that she undertakes the naming of Ikem's child" (Echeruo, 2013). In Liberia, a Beatrice emerged in Ellen Johnson who "set up the truth and reconciliation commission to promote national peace, security, unity and reconciliation by investigating more than twenty years of civil conflict in the country" (Wikipedia). She was able to resolve the unrest in Liberia and even won a Nobel Peace Prize for her efforts. Achebe in As remarks about women thus: "Let us keep her in reserve until the ultimate crisis arrives and the waist is broken and hung over the fire and the palm bears its fruit at the tail of its leaf. Then as the world crashes around man's ears, woman in her supremacy will descend and sweep the shards together" (AS, p. 89). This is exactly what happened in Liberia and Nigeria with the likes of Professor Dora Akwuyili who at huge risk reformed the pharmaceutical industry in Nigeria. Achebe's Chris is symbolic of a leader that would readily lay down his life for the helpless masses. As Ojinmah (1991, pp. 98-99) puts it "Chris was willing, even at the risk of his own life, to do the things he thought should be done such as protecting innocent civilians from the excesses of gun- trotting men in uniform." Achebe uses him to symbolize the past, the present and the future life of courage and martyrdom that most freedom fighters, government critics and activists live. The fate of Chris in the novel keeps recurring at police and army road blocks in Nigeria. A recent manifestation is the catastrophic killing of Professor Festus Iyayi, former ASUU President and Commonwealth Literary Prize winner, in a similar circumstance on the Lokoja-Abuja road on the $12^{\text {th }}$ of November, 2013. A police van in the Kogi State Governor's convoy deliberately left its lane and rammed in on the ASUU (Academic Staff Union of Universities) bus in which Festus Iyayi and three other ASUU officials were travelling. According to Ebhomele (2013) in an online news report, "Iyayi died at 66, in Lokoja, the Kogi State Capital, on his way to Kano for a meeting of the 
ASUU National Executive Council concerning the over-four months old strike embarked upon by the Union"(n.pag). Iyayi died in the motoring accident as claimed; however, his mortuary pictures later printed in the news magazine showed that he was mercilessly shot in the heart at close range just as Chris was shot too.

Furthermore, Amaechina, the girl child newly born towards the end of the novel, embodies a deep prophetic and symbolic syntagma. Since traditionally, there are some roles which females are either not allowed to perform or presumed as not having the capacity to, Achebe creates a situation in which a female child is given Amaechina, a male name in the Igbo language meaning "may the path never close," thereby conferring on the girl child all the attributes and potentials of a man.

\section{Minor Characters as Symbolic Syntagmas}

Few minor characters are identified and analysed as prophetic and symbolic syntagmas in table five.

Table 5: A Table of Minor Characters as Examples of Prophetic Syntagmas

\begin{tabular}{|c|c|c|c|c|}
\hline $\mathrm{S} / \mathrm{N}$ & Names & Page & Setting/Context & Associative Relations \\
\hline 1 & $\begin{array}{l}\text { Mad } \\
\text { Medico }\end{array}$ & $\begin{array}{l}\text { Many } \\
\text { pages. }\end{array}$ & $\begin{array}{l}\text { He is a friend of Chris, Ikem } \\
\text { and Sam who was deported } \\
\text { in by the military junta in } \\
\text { the novel. }\end{array}$ & $\begin{array}{l}\text { He has associative relations with Patrick } \\
\text { Wilmot, the Sociology scholar whom General } \\
\text { Babaginda (Nigeria Head of State, 1985-1993) } \\
\text { claimed to be a spy and teaching subversive } \\
\text { doctrines and so deported him in 1988, a year } \\
\text { after } A S \text { was published. }\end{array}$ \\
\hline 2 & Elewa & $\begin{array}{l}\text { Many } \\
\text { pages. }\end{array}$ & $\begin{array}{l}\text { She is the illiterate girl } \\
\text { friend of Ikem and mother } \\
\text { of Amaechina. }\end{array}$ & $\begin{array}{l}\text { She is a prophetic symbol of courage having } \\
\text { associative relations with the masses and } \\
\text { women coming into power. }\end{array}$ \\
\hline 3 & Agatha & $\begin{array}{l}\text { Many } \\
\text { pages. }\end{array}$ & $\begin{array}{l}\text { She is the Beatrice's } \\
\text { housemaid who refuses to } \\
\text { serve Elewa. }\end{array}$ & $\begin{array}{l}\text { She has associative relations with the masses at } \\
\text { loggerheads with one another and hardly able to } \\
\text { unite against bourgeois oppressions. }\end{array}$ \\
\hline 4 & $\begin{array}{l}\text { Elewa's } \\
\text { Uncle }\end{array}$ & 226 & $\begin{array}{l}\text { He is the elder to name the } \\
\text { newly born girl child, but } \\
\text { before he could arrive, the } \\
\text { youths had named her. }\end{array}$ & $\begin{array}{l}\text { He is a prophetic symbol of dying traditions and } \\
\text { the rise of youths and modernism. }\end{array}$ \\
\hline 5 & $\begin{array}{l}\text { The } \\
\text { Masses }\end{array}$ & $\begin{array}{l}\text { Many } \\
\text { pages, }\end{array}$ & $\begin{array}{l}\text { They are the students, taxi } \\
\text { drivers, etc. who support } \\
\text { Ikem and Chris. }\end{array}$ & $\begin{array}{l}\text { They are prophetic character symbols from } \\
\text { whom good leaders, support, love and loyalty } \\
\text { will be drawn. }\end{array}$ \\
\hline
\end{tabular}

\section{CONCLUSION}

The essay examined the prophetic syntagmas in $A S$ using Ferdinard de Saussure's concept of syntagma and the literary concept of symbolism as theoretical framework. The paper identified and analyzed some linguistic and literary syntagmas as symbolic and prophetic. The associative analysis of the syntagmas reveals striking replicas that manifested later in real life. The paper established that literature has the inherent power to predict and foreshadow with the apt deployment of language and literary features and that Achebe is a literary prophet who deployed his clairvoyant literary prowess to invest his characters, events, settings and grammatical structures with prophecies and symbolisms for Nigeria and Africa. The prophetic syntagmas used in the novel portray and confirm Achebe's literary clairvoyance and prophetic insight. 


\section{REFERENCES}

Abrams, M.H, \& Harpham, G.G. (2009). A glossary of literary terms. 9th ed. Boston: Wadsworth.

Achebe, C. (1987). Anthills of the savannah. Ibadan: Heinemann.

Achebe, C. (1966). A man of the people. London: Heinemann.

Ademosun, F. (2013). Festus Iyayi: Assassination or Accident?. Sahara Reporters: News and Reports. 3 Nov. 2013. Retrieved from the Web. 13 Mar. 2014.

Chandler, D. (2007). Semiotics for beginners. Retrieved from http://www.aber.ac.uk/media/docu ments/54B/semiotic.htm. 13 Feb. 2013.

Crystal, D. 2009. A Dictionary of linguistics and phonetics. Oxford: Blackwell.

Ebhosele, E. (2013). Outrage over killing of Festus Iyayi by police escort truck in Kogi governor's convoy. Retrieved from Sahara Reporters. 13 Mar. 2014.

Echeruo, M.J.C. (1998). Chinua Achebe's Anthills of the Savannah: Post-history and biblical example. Theoria: A Journal of Social and Political Theory. 91, 66-86.

Ekundayo, S. B. (2002). Total literature in English (2nd ed). Benin: Nobel Publishers.

Ekundayo, S.B., \& Iyayi, F. (2013). The place of literature in individual and national development. Journal of the Literary Society of Nigeria (JLSN).5, 83-93.

Miles, A. (2000). Hypertext syntagmas: Cinematic narration with links. Journal of Digital Information 1.7, 1-2.

Ngara, E. (1990). The place and significance of Anthills of the Savannah, pp. 247-263. In Edith Ihekweazu Ed. Eagle on Iroko: Selected papers from the Chinua Achebe International Symposium 1990. Ibadan: Johnmof.
Ogiovoh, E. E. (2005). Multiple points of view and the fight against oppression in Achebe's Anthills of the Savannah. Long Essay. University of Benin,

Ojinmah, U. (1991). Chinua Achebe: New perspectives. Ibadan: Spectrum.

Okafor, K. (1990). The Quest for social change: Reformation or revolution. Eagle on Iroko: Selected Papers from Chinua Achebe International Symposium 1990. Ed. Edith Ihekweazu. Ibadan: Johnmof.

Owomoyela, O. (2002). Discourse on gender: Historical contingency and ethics of intellectual work. West African Review, $1-12$.

Reuters. (2009). Ken Saro-Wiwa. The New York Times. Capital one 360. Retrieved from the Web March, 2013.

Richards, J.C., Platt, J., \& Platt, H. (1992). Longman dictionary of language teaching and applied linguistics. London: Longman.

Saussure, de F. (966). A course in general linguistics. Trans. Wade Baskin. New York: McGraw Hill.

Silvers, A. (1991). The story of art is the test of time. The Journal of Aesthetics and Art Criticism 49(3),211-224.

USA Today. 2007- 2013. Product description. Amazonfresh. Retrieved from the Web. 4 Feb. 2015.

Umukoro, S.O. (2009). Literary criticism, scholarship and national development. 18th Inaugural lecture of the Delta State University. Abraka: Delta State University Press.

Wikipedia: Ken Saro-Wiwa. Retrieved from <http://en.m.wikepedia.org/wiki/ke nsarowiwa>12 March, 2015.

Wikepedia: Ellen Johnson Sirleaf. Retrieved from Wikepedia <http://en.m.wikepedia.org/wiki/Ell en_johnson_sirleaf>12 Mar. 2015. 
